\title{
PENGARUH MODEL TPS BERMUATAN KEARIFAN LOKAL MENYAMA BRAYA TERHADAP SIKAP SOSIAL DAN PENGUASAAN KOMPETENSI PENGETAHUAN IPS
}

\author{
I Gst. Ayu Md Ernawati ${ }^{1}$, Dw. Nym. Sudana ${ }^{2}$, Ni Wyn. Rati ${ }^{3}$ \\ Prodi Pendidikan Dasar, Universitas Pendidikan Ganesha, Singaraja \\ e-mail: ernawati118888@gmail.com ${ }^{1}$, sudanadewanyomanpgsd@yahoo.co.id ${ }^{2}$, niwayan_rati@yahoo.co.id ${ }^{3}$
}

\begin{abstract}
Abstrak
Masalah rata-rata skor penguasaan kompetensi pengetahuan IPS siswa kelas IV Gugus II Kecamatan Abiansemal tergolong rendah. Oleh karena itu, penelitian ini bertujuan untuk mengetahui pengaruh model pembelajaran kooperatif tipe TPS bermuatan kearifan lokal menyama braya terhadap sikap sosial dan penguasaan kompotensi pengetahuan IPS siswa. Penelitian ini merupakan penelitian, eksperimen semu dengan rancangan Posttest Only Control Group Design. Populasi penelitian ini adalah kelas IV SD di Gugus II kecamatan Abiansemal Tahun Pelajaran 2018/2019. Pengambilan sampel menggunakan teknik random sampling. Sampel dalam penelitian ini adalah siswa kelas IV SD No 1 Selat berjumlah 41 orang sebagai kelas eksperimen dan SD No 1 Punggul berjumlah 30 orang sebagai kelas kontrol. Pengumpulan data sikap sosial dilakukan dengan menggunakan metode non tes berupa kuesioner dan pengumpulan data penguasaan kompotensi pengetahuan IPS dilakukan dengan menggunakan metode tes berupa tes pilihan ganda. Teknik analisis data yang digunakan adalah statistik deskriptif dan inferensial (ANAVA-A dan MANOVA). Ratarata skor sikap sosial siswa kelas eksperimen 148,78 termasuk dalam katagori tinggi dan di kelas kontrol 126,30 termasuk dalam katagori cukup sedangkan rata-rata penguasaan kompotensi pengetahuan IPS siwa di kelas eksperimen 25,61 termasuk dalam katagori baik dan di kelas kontrol 20,60 termasuk dalam katagori cukup. Hasil hipotesis I menunjukkan bahwa $F=89,331$, Hasil hipotesis II menunjukkan bahwa $F=114,964$, dan Hasil hipotesis III menunjukkan bahwa $F=2118,488$. Berdasarkan hasil penelitian tersebut dapat disimpulkan bahwa terdapat pengaruh model pembelajaran kooperatif tipe TPS bermuatan kearifan lokal menyama braya terhadap sikap sosial dan penguasaan kompotensi pengetahuan IPS siswa kelas IV Gugus II Kecamatan Abiansemal Tahun Pelajaran 2018/2019.
\end{abstract}

Kata kunci: TPS, kearifan lokal menyama braya, sikap sosial, kompotensi pengetahuan IPS

\begin{abstract}
The problem of the average score of mastery of social science competency knowledge in class IV of Group II of Abiansemal District is low. Therefore, this study aims to determine the effect of cooperative learning models of think pair share type of charged local wisdom together on social attitudes and mastery of students' social science competency knowledge. This research is a research, a quasi-experimental design with Posttest Only Control Group Design. The population of this study is class IV elementary school in Cluster II sub-district Abiansemal Academic Year 2018/2019. Sampling uses random sampling technique. The sample in this study were fourth grade students of SD No. 1 Selat totaling 41 people as the experimental class and SD No. 1 Punggul totaling 30 people as the control class. Data collection on social attitudes was carried out using a non-test method in the form of a questionnaire and data collection on mastery of competency in social science knowledge was carried out using the test method in the form of multiple choice tests. The data analysis technique used is descriptive and inferential statistics (ANAVA-A and MANOVA). The average score of the social attitude of the experimental class students 148.78 is included in
\end{abstract}


the high category and in the control class 126.30 is included in the sufficient category while the average mastery of students' knowledge of IPS students in the experimental class 25.61 is included in the good category and in the control class 20.60 is included in the sufficient category. The results of hypothesis I show that $F=89,331$, Results of hypothesis II indicate that $F=114,964$, and Results of hypothesis III indicate that $F=2118,488$. Based on the results of this study it can be concluded that there is the influence of cooperative learning models think pair share with local wisdom loaded together with respect to social attitudes and mastery of the competency of social science knowledge students of class IV of Cluster II District Abiansemal Academic Year 2018/2019.

Key words: TPS, local wisdom equates to social, social attitudes, social science competency

\section{PENDAHULUAN}

Pendidikan adalah usaha sadar dan terencana untuk mewujudkan suasana belajar dan proses pembelajaran agar peserta didik secara aktif mengembangkan potensi dirinya untuk memiliki kekuatan spiritual keagamaan, pengendalian diri, kepribadian, kecerdasan, akhlak mulia, serta keterampilan yang diperlukan dirinya, masyarakat, bangsa dan negara. pendidikan adalah suatu bentuk perwujudan dalam rangka mempengaruhi peserta didik supaya mampu menyesuaikan diri sebaik mungkin dengan lingkungannya, yang akan menimbulkan perubahan dalam dirinya untuk mewujudkan suasana belajar dan proses pembelajaran agar peserta didik secara aktif mengembangkan potensi dirinya, untuk pengendalian diri agar berguna dalam kehidupan masyarakat, bangsa dan negara.

Kurikulum saat ini menuntut perkembangan kualitas pendidikan yang lebih baik dan lebih maju. Kurikulum 2013 menekankan pada pentingnya pembentukan karakter siswa di sekolah, terutama pada pendidikan dasar. "Kurikulum 2013 bertujuan untuk mempersiapkan manusia Indonesia agar memiliki kemampuan hidup sebagai pribadi dan warga negara yang beriman, produktif, kreatif, inovatif, dan afektif serta mampu berkontribusi pada kehidupan bermasyarakat, berbangsa, dan bernegara" (Kunandar, 2015:16). Pada kurikulum 2013 pembelajaran IPS di sekolah dasar terkandung dalam tema pembelajaran. Dalam satu tema terdapat beberapa sub tema dan dalam satu sub tema terdiri dari beberapa pembelajaran. "IPS adalah ilmu untuk mengembangkan konsep pemikiran yang berdasarkan realita kondisi sosial yang ada di lingkungan siswa, sehingga dengan memberikan pendidikan IPS diharapkan dapat melahirkan warga negara yang baik dan bertanggung jawab terhadap bangsa dan negaranya" (Susanto, 2014:138).

Berdasarkan hasil wawancara yang dilakukan disekolah pada tanggal 14 Januari 2019 samapai 15 Januari 2019 yang telah dilakukan dengan guru kelas IV Gugus II Kecamatan Abiansemal. Guru menyampaikan bahwa Siswa kurang berminat pada pelajaran IPS, karena mereka susah dalam mengingat materi yang saya ajarkan, guru hanya sesekali saja menyocokkan dengan tema, misalnya tema satu menggunakan model TPS, maka tema-tema selanjutnya saya menggunakan model tersebut.

Berdasarkan hasil pencatatan dokumen tentang nilai kompotensi pengetahuan mata pelajaran IPS siswa kelas IV Gugus II Kecamatan Abiansemal menunjukkan bahwa hasil kompotensi pengetahuan IPS siswa masih tergolong rendah. Terlihat dari hasil ujian akhir semester siswa pada mata pelajaran IPS masih banyak dibawah Kriteria Ketuntasan Minimal (KKM). Nilai (UAS) kompotensi pengetahuan IPS siswa kelas IV Gugus II Kecamatan Abiansemal Kabupaten Badung, dapat dilihat pada Tabel 1 berikut. 
PIPS, Vol. 3 No. 1, Bulan April Tahun 2019

ISSN:2614-8366

Tabel 1

Jumlah Siswa yang Mencapai dan Tidak Mencapai KKM

\begin{tabular}{|c|c|c|c|c|c|c|c|}
\hline \multirow[t]{2}{*}{ No. } & \multirow[t]{2}{*}{ Nama Sekolah } & \multirow[t]{2}{*}{ KKM } & \multirow{2}{*}{$\begin{array}{c}\text { Jumlah } \\
\text { Siswa }\end{array}$} & \multicolumn{2}{|c|}{$\begin{array}{c}\text { Siswa yang } \\
\text { Mencapai KKM }\end{array}$} & \multicolumn{2}{|c|}{$\begin{array}{l}\text { Siswa yang Belum } \\
\text { Memcapai KKM }\end{array}$} \\
\hline & & & & Siswa & $\%$ & Siswa & $\%$ \\
\hline \multirow{2}{*}{$\begin{array}{l}1 \\
2\end{array}$} & SD No 1 Selat & 76 & 41 & 18 & 44 & 23 & 56 \\
\hline & $\begin{array}{l}\text { SD No } 1 \\
\text { Punggul }\end{array}$ & 70 & 30 & 15 & 50 & 15 & 50 \\
\hline 3 & $\begin{array}{l}\text { SD No } 2 \\
\text { Punggul }\end{array}$ & 71 & 21 & 11 & 52 & 10 & 47 \\
\hline 4 & SD No 1 Taman & 76 & 29 & 12 & 41 & 17 & 58 \\
\hline 5 & SD No 2 Taman & 76 & 24 & 14 & 58 & 10 & 42 \\
\hline 6 & SD No 3 Taman & 76 & 17 & 6 & 35 & 11 & 65 \\
\hline 7 & SD No 4 Taman & 72 & 11 & 5 & 45 & 6 & 55 \\
\hline 8 & SD No 5 Taman & 76 & 22 & 10 & 45 & 12 & 55 \\
\hline \multicolumn{2}{|c|}{ Jumlah } & & 195 & 91 & 47 & 104 & 53 \\
\hline
\end{tabular}

Berdasarkan Tabel 1 dinyatakan bahwa jumlah siswa kelas IV secara keseluruhan 195 orang. Dari jumlah siswa tersebut, siswa yang sudah mencapai KKM sebanyak 91 orang atau $47 \%$ dan siswa yang belum mencapai KKM sebanyak 104 orang atau 53\%. Jika dilihat dari uraian tersebut terlihat bahwa hasil belajar IPS siswa kelas IV masih perlu untuk di tingkatkan lagi sehingga, hasil belajar semua siswa kelas IV dapat mencapai KKM yang telah ditentukan.

Pada proses pembelajaran berlangsung saat guru meminta siswa mengerjakan tugas bersama kelompok siswa belum mamapu bekerjasama dan masih ada siswa yang bercanda, sehingga terlihat bahwa sikap sosial siswa terlihat rendah. Untuk mengoptimalkan pembelajaran agar peserta didik mampu secara optimal menuangkan gagasannya di dalam pembelajaran, perlu digunakannya model pembelajaran yang inovatif. Salah satu model pembelajaran yang cocok digunakan adalah model pembelajaran kooperatif tipe think pair share bermuatan kearifan lokal menyama braya. Slavin (2010:4) menyatakan bahwa, "Pembelajaran kooperatif merujuk pada berbagai macam metode pengajaran untuk siswa bekerja secara berkelompok untuk saling membantu satu sama lainnya dalam mempelajari materi pelajaran". Di dalam kelas, para siswa diharapkan dapat saling membantu, saling mendiskusikan dan beragumentasi, untuk mengasah pengetahuan yang mereka kuasai saat itu dan menutup kesenjangan dalam pemahaman masing-masing. Model pembelajaran kooperatif adalah model pembelajaran dengan cara siswa bekerja berkelompok untuk bekerjasama saling membantu, memotivasi, mengkonstruksi konsep, menyelesaikan persoalan secara bersama-sama untuk mencapai tujuan bersama dalam pembelajaran. Model ini memiliki keunggulan untuk dapat mengembangkan kemampuan mengungkapkan gagasan sehingga dapat saling membantu satu sama lain. Meningkatkan partisipasi siswa sehingga tanya jawab dapat berlangsung dengan baik yang mendorong pembangunan pengetahuan secara integratif. Menurut Arends (2013:159), "tujuan pembelajaran kooperatif ada ketika siswa menganggap bahwa mereka dapat mencapai tujuan mereka jika, siswa lain yang bekerja sama dengan mereka dapat juga mencapai tujuan".

Pada model pembelajaran kooperatif tipe think pair share bermuatan kearifan lokal menyama braya dilakukan untuk mengetahui sejauh mana keakuratan model ini. Model pembelajaran kooperatif tipe think pair share bermuatan kearifan lokal menyama braya merupakan suatu model pembelajaran yang efektif untuk mengendalikan kelas secara keseluruhan dan prosedur yang digunakan dalam think pair share bermuatan kearifan lokal menyama braya dapat memberikan siswa lebih banyak waktu untuk berpikir, merespon, dan saling bekerja sama dengan teman dalam kelompoknya. Model pembelajaran kooperatif tipe think pair share bermuatan kearifan lokal menyama braya atau berpikir, berpasangan, berbagi merupakan jenis pembelajaran kooperatif yang dirancang untuk mepengaruhi pola 
interaksi siswa. Model pembelajaran kooperatif tipe think pair share bermuatan kearifan lokal menyama braya mudah untuk digunakan sebab dapat mengefisienkan waktu dengan tidak mengatur tempat duduk siswa untuk membetuk kelompok. Model pembelajaran ini siswa dilatih bagaimana mengutarakan pendapat dan siswa juga belajar menghargai pendapat orang lain dengan tetap mengacu pada materi atau tujuan pembelajaran. Pembelajaran akan lebih menarik apabila dalam proses pembelajaran diberikan media berupa gambar atau simbol-simbol yang menarik perhatian siswa untuk mengikuti proses pembelajaran sehingga siswa mampu menggali pengetahuannya secara optimal. Keunggulan dari model pembelajaran model kooperatif tipe think pair share bermuatan kearifan lokal menyama braya di antaranya: (1) model ini dengan sendirinya memberikan kesempatan yang banyak kepada siswa untuk berfikir, menjawab, dan saling membantu satu sama lain. (2) dapat meningkatkan partisipasi siswa dalam proses pembelajaran. (3) dengan pembelajran TPS ini dapat diminimalisir peran sentral guru, sebab semua siswa akan terlibatdengan permasalahan yang diberikan guru.

Menurut Kurniasih (2014:117) "sikap sosial adalah sikap yang diarahkan untuk kepentingan pengembnagan kompotensi sosial. Kompotensi sosial tersebut meliputi jujur, disiplin, tanggung jawab, toleransi, gotong royong, sopan santun, dan percaya diri". Masalah sikap sosial adalah masalah yang erat hubungannya dengan norma dan sistem nilai yang terdapat dalam kelompok dimana individu menjadi anggota yang berhasrat mengadakan hubungan struktural oranisatoris dan atau berhasrat mengadakan hubungan psikologis.

Kompetensi adalah sesuatu yang kompleks yang di dalamnya mengandung banyak aspek (ranah). Menurut Permendikbud Nomor 57 Tahun 2014 lampiran I Tentang Kurikulum 2013 Sekolah Dasar/Madrasah Ibtidaiyah. Kompetensi Inti Sekolah Dasar/Madrasah Ibtidaiyah (SD/MI) merupakan tingkat kemampuan untuk mencapai Standar Kompetensi Lulusan (SKL) yang harus dimiliki seorang peserta didik SD/MI pada setiap tingkat kelas. Kompetensi Inti dirancang untuk setiap kelas/usia tertentu.

Menurut Susanto (2015), Ilmu Pengetahuan Sosial atau yang sering disingkat dengan IPS merupakan suatu ilmu pengetahuan yang lebih banyak mengkaji tentang kehidupan sosial. "Ilmu Pengetahuan Sosial adalah ilmu pengetahuan yang mengkaji berbagai disiplin ilmu sosial dan humaniora, serta kegiatan manusia yang dikemas secara ilmiah dalam rangka memberi wawasan dan pemahaman yang mendalam kepada pesera didik, khususnya di tingkat dasar dan menengah. Menurut Susanto (2015:137) "Hakikat pendidikan IPS hendaknya dikembangkan berdasarkan realita kondisi sosial budaya yang ada di lingkungan siswa, sehingga dengan ini akan dapat membina warga negara yang baik yang mampu memahami dan menelaah secara kritis kehidupan sosial di sekitarnya, serta mampu secara aktif berpartisipasi dalam lingkungan kehidupan, baik di masyarakatnya, negara, maupun dunia".

Menurut Slavin (2010:4), "pembelajaran kooperatif merujuk pada berbagai macam metode pengajaran di mana para siswa bekerja dalam kelompok-kelompok kecil untuk saling membantu satu sama lainnya dalam mempelajari materi pelajaran". Dalam metode pembelajaran kooperatif, para siswa akan duduk bersama dalam kelompok yang beranggotakan empat sampai lima orang untuk menguasai materi yang disampaikan oleh guru. Di dalam kelas kooperatif, para siswa diharapkan dapat saling membantu, saling mendiskusikan dan beragumentasi, untuk mengasah pengetahuan yang mereka kuasai saat itu dan menutup kesenjangan dalam pemahaman masing-masing. Syarifuddin Nurdin (2016:182) menyatakan bahwa, "pembelajaran kooperatif adalah pembelajaran aktif yang menekankan aktivitas siswa bersama-sama secara berkelompok dan tidak individual. Siswa secara berkelompok mengembangkan kecakapan hidupnya seperti menemukan dan memecahkan masalah, pengambilan keputusan, berfikir logis, berkomunikasi efektif dan bekerja sama".

Model pembelajaran tipe think pair share bermuatan kearifan lokal menyama braya merupakan salah satu tipe dari model pembelajaran kooperatif. Model pembelajaran kooperatif tipe think pair share bermuatan kearifan lokal menyama braya dikembangkan pertama kali oleh Frank Lyman di Universitas Maryland. Dia menyatakan bahwa TPS 
merupakan suatu cara yang efektif untuk mengganti suasana pola diskusi kelas, dengan asumsi bahwa diskusi membutuhkan pengaturan untuk mengendalikan kelas secara keseluruhan dan prosedur yang digunakan dalam think pair share bermuatan kearifan lokal menyama braya dapat memberikan siswa lebih banyak waktu untuk berpikir, merespon, dan saling bekerja sama dengan teman dalam kelompoknya. Ketika guru menyampaikan pelajaran kepada kelas, para siswa duduk berpasangan dengan timnya masing-masing. Guru memberikan pertanyaan kepada kelas. Siswa diminta untuk memikirkan sebuah jawaban dari mereka sendiri, lalu berpasangan dengan pasangannya untuk mencapai sebuah kesepakatan terhadap jawaban. Kemudian guru meminta siswa untuk berbagi jawaban yang telah mereka sepakati dengan seluruh kelas (Slavin, 2010).

Menurut Suja (2010), kearifan lokal adalah tindakan hanya mengandung makna bahwa kearifan tersebut tumbuh dari pemecahan masalah yang bersifat lokal, tetapi kesahihannya pun terbatas pada lingkungan dimana dia tumbuh dan berkembang. Kearifan lokal juga berperan penting dalam mempertebal kohesi sosial diantara warga masyarakat bersangkutan.

Menurut surya (2017), menyama braya adalah merupakan konsep ideal hidup bermasyarakat di bali yang bersumber dari sistem nilai budaya dan adat istiadat masyarakat bali untuk dapat hidup rukun. Menyama Braya mengandung makna persamaan dan persaudaraan dan pengakuan sosial sebagai satu kesatuan sosial persaudaran maka sikap dan perilaku dalam memandang orang lain sebagai saudara yang patut diajak bersama dalam suka maupun duka.

Tujuan pembelajaran ini adalah untuk mengetahui pengaruh model pembelajaran kooperatif tipe think pair share bermuatan kearifan lokal menyama braya terhadap sikap sosial dan penguasaan kompotensi pengetahuan IPS siswa antara siswa yang tidak dibelajarkan model pembelajaran kooperatif tipe think pair share bermuatan kearifan lokal menyama braya terhadap sikap sosial dan penguasaan kompotensi pengetahuan IPS siswa.

\section{METODE}

Penelitian ini dilaksanakan pada rentang waktu semester II (genap) tahun pelajaran 2018/2019 yang dilaksanakan di Gugus II Kecamatan Abiansemal. Jenis penelitian yang dilakukan adalah penelitian eksperimen semu. Penelitian eksperimen merupakan penelitian yang bertujuan untuk menguji keefektifan suatu teori/konsep/model dengan cara menerapkan (treatment) pada satu kelompok subjek penelitian dengan menggunakan kelompok pembanding yang biasa disebut kelompok kontrol Agung (2016). Penelitian ini menggunakan rancangan penelitian eksperimen semu (quasy experiment) karena tidak semua variabel yang muncul dalam kondisi eksperimen dapat diatur dan dikontrol secara ketat (full randomize). Namun dalam penelitian ini, terdapat satu variabel yang dikontrol yaitu hasil belajar. Variabel kontrol itupun tidak dapat dikontrol secara ketat.

Pada penelitian ini akan dilaksanakan pada kelas IV semester II Gugus II Kecamatan Abiansemal Kabupaten Badung Tahun Pelajaran 2018/2019. Jenis penelitian ini merupakan jenis penelitian eksperimen semu (quasi experiment). Rancangan penelitian ini menggunakan Rancangan Posttest Only Control Group Design. Dalam rancangan ini, ada dua kelompok subjek yaitu satu kelompok mendapat perlakuan (eksperimen) dan satu kelompok sebagai kelompok kontrol. Kedua kelompok memperoleh post test. Pola Rancangan Kelompok Kontrol Non-ekuivalen (Posttest Only Control Group Design) disajikan sebagai berikut. 
PIPS, Vol. 3 No. 1, Bulan April Tahun 2019

ISSN:2614-8366

Tabel 2

Posttest Only Control Group Design

\begin{tabular}{ccc}
\hline Kelompok & Perlakuan & Post Test \\
\hline $\mathrm{R}$ & $\mathrm{X}$ & $\mathrm{O}_{1}$ \\
$\mathrm{R}$ & - & $\mathrm{O}_{2}$ \\
\hline
\end{tabular}

(Dantes, 2017)

Keterangan:

$\mathrm{R} \quad=$ Randominasi sampel

$\mathrm{X}=$ Kelompok yang diberikan perlakuan dengan model pembelajaran kooperatif tipe Think Pair Share

- $\quad=$ Kelompok yang tidak diberikan perlakuan dengan model kooperatif tipe Think Pair Share

$\mathrm{O}_{1} \quad=$ Post-test pada kelompok eksperimen

$\mathrm{O}_{2} \quad=$ Post-test pada kelompok kontrol

Populasi dalam penelitian ini adalah siswa kelas IV di SD Negeri yang terdapat pada SD di Gugus II Kecamatan Abiansemal. Menurut Sugiyono (2011:80) "populasi adalah wilayah generalisasi yang terdiri atas : objek/subjek yang mempunyai kualitas dan karakteristik tertentu yang ditetapkan oleh peneliti untuk dipelajari dan kemudian ditarik kesimpulannya". Sedangkan pendapat dari Setyosari (2012:221) menyatakan bahwa: "populasi adalah keseluruhan objek, orang, peristiwa, atau sejenisnya yang menjadi perhatian dan kajian dalam suatu penelitian".

Teknik pengambilan sampel pada penelitian ini adalah dengan teknik random sampling. Random Sampling adalah pengambilan anggota sampel pada tiap-tiap populasi dilakukan secara acak, namun tetap memberikan kesempatan kepada seluruh populasi. Dalam penelitian ini setiap kelas memperoleh hak yang sama dan mendapat kesempatan dipilih menjadi sampel. Pengacakan yang dilakukan adalah dengan cara 2 kali pengundian. Pertama-tama dilakukan dengan cara menuliskan nama sekolah di dalam kertas, kemudian kertas tersebut digulung dan diacak-acak, setelah itu diambil secara acak untuk menentukan sekolah yang dijadikan sebagai kelompok eksperimen. Setelah itu kembali melakukan pengundian dengan jumlah sekolah yang berkurang satu yang masih tersisa jumlah tujuh sekolah, yaitu dengan cara pengundian kedua kalinya, mengambil secara acak lagi untuk mengambil nama sekolah yang dijadikan sebagi kelompok ekperimen dan kelompok kontrol.

Dalam pemilihan kelas eksperimen dan kelas kontrol dilakukan dengan dibagi dengan teknik undian. Berdasarkan hasil undian kelas eksperimen dan kontrol, diperoleh siswa kelas IV SD No 1 Selat yang sebagai kelas eksperimen dan siswa kelas IV SD No 1 Punggul yang sebagai kelas kontrol. Kelas eksperimen diberikan perlakuan pembelajaran dengan menggunakan model pembelajaran kooperatif tipe think pair share bermuatan kearifan lokal menyama braya dan kelas kontrol diberikan perlakuan pembelajaran dengan tidak mengikuti model pembelajaran kooperatif tipe think pair share bermuatan kearifan lokal menyama braya.

Pengujian hipotesis pertama dan kedua menggunakan analisis varians (ANAVA) dengan bantuan SPSS 17.00 for windows. Pengujian anatara subjek dilakukan terhadap angka-angka signifikan dari nilai $\mathrm{F}$ dengan angka signifikan lebih kecil dari 0,05 berarti $\mathrm{H}_{0}$ ditolak yang artinya terdapat perbedaan variabel dependen antar kelompok. Untuk pengujian hipotesis yang ketiga dilakukan uji MANOVA dengan bantuan SPSS 17.00 for windows.

\section{HASIL dan PEMBAHASAN}

Data hasil post-test sikap sosial pada kelompok eksperimen diperoleh dari 41 orang siswa, sikap sosial pada kelompok eksperimen dapat disajikan ke dalam bentuk grafik polygon sebagai berikut. 


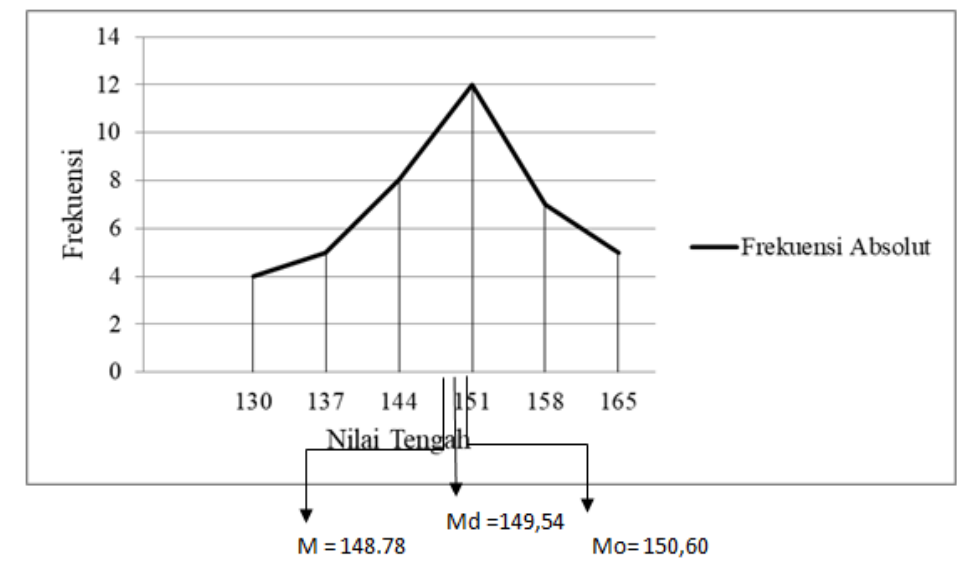

Gambar 1. Grafik Polygon Data Hasil Post-test Sikap Sosial Kelompok Eksperimen

Berdasarkan grafik polygon di atas, nilai modus (Mo), median (Md), dan mean (M) digambarkan dari grafik polygon, tampak bahwa kurva sebaran nilai kelompok eksperimen merupakan kurva juling negatif, karena $M<M d<M o(148,78<149,54<150,61)$. Hal ini menunjukkan bahwa sebagian besar skor sikap sosial pada kelompok eksperimen cenderung tinggi.

Data hasil post-test sikap sosial pada kelompok kontrol diperoleh dari 30 orang siswa, sikap sosial pada kelompok kontrol dapat disajikan ke dalam bentuk grafik polygon sebagai berikut.

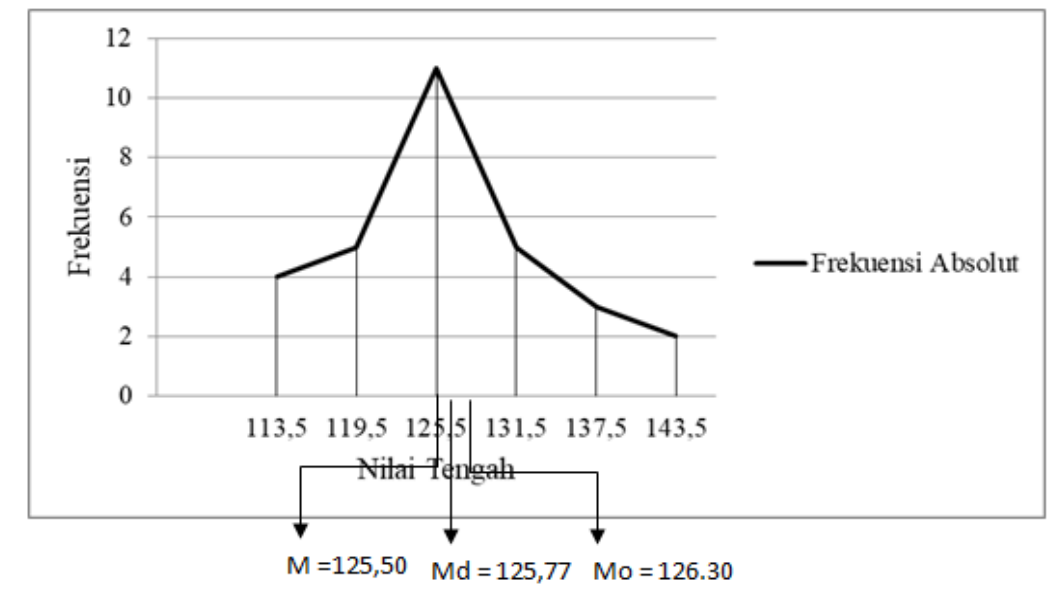

Gambar 2. Grafik Polygon Data Hasil Post-test Sikap Sosial Kelompok Kontrol

Berdasarkan grafik polygon di atas, nilai modus (Mo), median (Md), dan mean (M) digambarkan dari grafik polygon, tampak bahwa kurva sebaran nilai kelompok kontrol merupakan kurva juling positif, karena Mo < $M d<M(125,50<125,77<126,30)$. Hal ini menunjukkan bahwa sebagian besar skor sikap sosial pada kelompok kontrol cenderung rendah.

Data hasil post-test sikap sosial pada kelompok kontrol diperoleh dari 30 orang siswa, data hasil post-test kompetensi pengetahuan IPS kelompok eksperimen dapat disajikan ke dalam bentuk grafik polygon sebagai berikut 


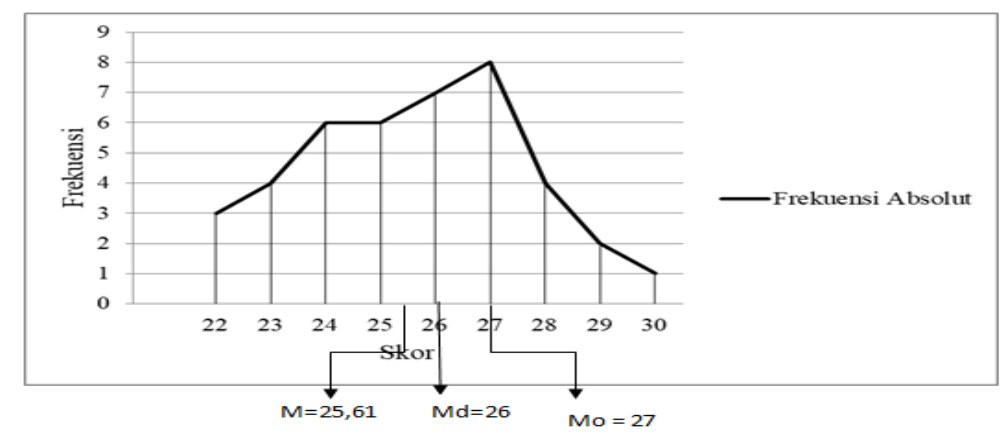

Gambar 3. Grafik Polygon Data Hasil Post-test Kompetensi Pengetahuan IPS Kelompok Eksperimen

Berdasarkan grafik polygon di atas, nilai kelompok eksperimen merupakan kurva juling negatif, karena $\mathrm{M}<\mathrm{Md}<\mathrm{Mo}(25,61<26<27)$. Hal ini menunjukkan bahwa sebagian besar skor kompetensi pengetahuan IPS pada kelompok eksperimen cenderung tinggi.

Data hasil post-test sikap sosial pada kelompok kontrol diperoleh dari 30 orang siswa, data hasil post-test kompetensi pengetahuan IPS kelompok kontrol dapat disajikan ke dalam bentuk grafik polygon sebagai berikut.

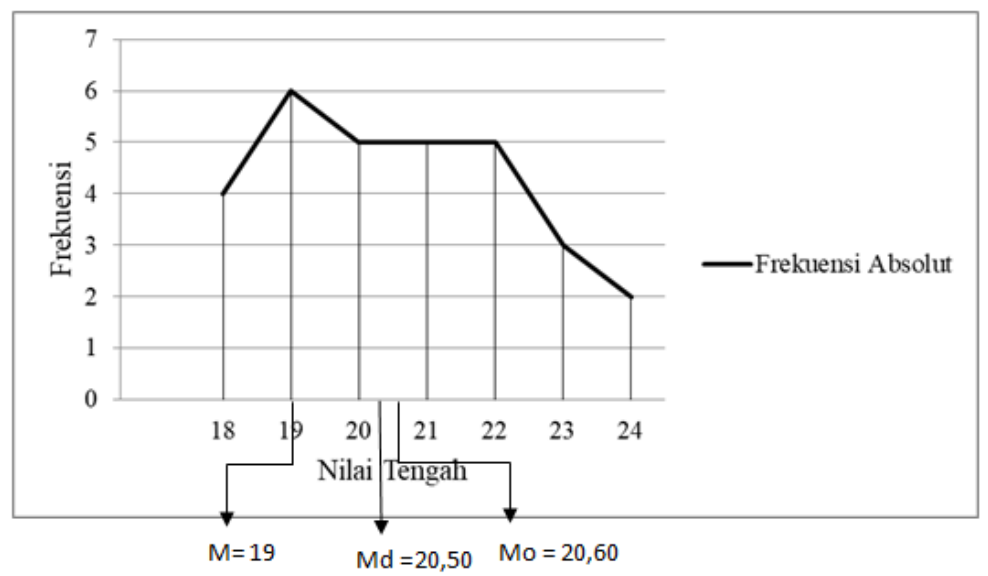

Gambar 4. Grafik Polygon Data Hasil Post-test Kompetensi Pengetahuan IPS Kelompok Kontrol.

Berdasarkan grafik polygon di atas, nilai kelompok kontrol merupakan kurva juling positif, karena Mo < Md < $\mathrm{M}(19<20,50<20,60)$. Hal ini menunjukkan bahwa sebagian besar skor kompetensi pengetahuan IPS pada kelompok kontrol cenderung rendah.

Berdasarkan penelitian yang telah dilakukan, secara deskriptif sikap sosial dan penguasaaan kompetensi pengetahuan IPS siswa kelas IV yang mengikuti model pembelajaran kooperatif tipe think pair share bermuatan kearifan lokal menyama braya memiliki rata-rata skor sikap sosial dan penguasaan kompetensi pengetahuan IPS lebih baik dari pada rata-rata skor sikap sosial dan penguasaan kompotensi pengetahuan IPS siswa yang tidak mengikuti model pembelajaran kooperatif tipe think pair share bermuatan kearifan lokal menyama braya.

Hasil analisis data tentang sikap sosial dan penguasaan kompetensi pengetahuan IPS menunjukkan, terdapat pengaruh yang simultan antara siswa yang mengikuti mengikuti model pembelajaran kooperatif tipe think pair share bermuatan kearifan lokal menyama braya dengan siswa yang tidak mengikuti mengikuti model pembelajaran kooperatif tipe think pair share bermuatan kearifan lokal menyama braya bermuatan kearifan lokal menyama braya memperoleh hasil analisis, nilai $F$ sebesar 89,311 dengan nilai signifikan 0,000 dan lebih kecil dari 0,05 , hal ini menunjukkan terdapat pengaruh secara silmutan sikap sosial dan penguasaan kompetensi pengetahuan IPS anata siswa yang mengikuti mengikuti model pembelajaran kooperatif tipe think pair share bermuatan kearifan lokal menyama braya 
dengan siswa yang tidak mengikuti mengikuti model pembelajaran kooperatif tipe think pair share bermuatan kearifan lokal menyama braya.

Bedasarkan tiga tahap pembelajaran TPS yaitu, think (berpikir Pada tahap berpikir ini guru mengajukan pertanyaan atau masalah yang dikaitkan dengan pelajaran, dan meminta siswa menggunakan waktu beberapa menit untuk berpikir sendiri jawaban atau masalah. Pada tahap ini, siswa sebaiknya menuliskan jawaban mereka, hal ini disebabkan karena guru tidak dapat memantau semua jawaban siswa sehingga melalui catatan tersebut guru dapat mengetahui jawaban yang harus diperbaiki atau diluruskan di akhir pembelajaran. Kelebihan dari tahap ini adalah adanya "think time" atau waktu berpikir yang memberikan kesempatan kepada siswa secara mandiri untuk berpikir mengenai jawaban mereka sebelum pertanyaan tersebut dijawab oleh siswa lain.

Pair (berpasangan) guru menugaskan siswa untuk berpasangan dan mendiskusikan apa yang telah mereka pikirkan. Interaksi selama waktu yang telah disediakan dapat menyatukan jawaban, suatu pertanyaan yang diajukan atau menyatukan gagasan apabila suatu masalah khusus yang diidentifikasi. Secara normal guru memberi waktu tidak lebih dari 4 atau 5 menit untuk berpasangan.

Share (berbagi) guru meminta pasangan-pasangan untuk berbagi dengan keseluruhan kelas yang telah mereka bicarakan dalam diskusi kelompok. Langkah ini akan menjadi efektif apabila guru aktif untuk memonitoring pasangan satu ke pasangan yang lain, sehingga seperempat atau setengah dari pasangan-pasangan tersebut memperoleh kesempatan untuk melapor. Langkah ini merupakan penyempurnaan dari langkah-langkah sebelumnya, dalam arti langkah ini menolong semua kelompok untuk lebih memahami mengenai pemecahan masalah yang diberikan berdasarkan penjelasan kelompok yang lain. "Adapun manfaat model pembelajaran TPS antara lain adalah: 1) memungkinkan siswa untuk bekerja sendiri dan bekerja sama dengan orang lain; 2) mengoptimalkan partisipasi siswa; dan 3) memberi kesempatan kepada siswa untuk menunjukkan partisipasi mereka kepada orang lain" (Huda, 2014:206).

Hasil penelitian ini diperkuat dengan hasil penelitian yang relevan dan memperkuata hasil penelitian yang diperoleh. Hasil tersebut didukung hasil penelitian yang diajukan oleh Suardika (2016), yang berjudul "Pengaruh model pembelajaran TPS berbasis pendekatan saintifik terhadap hasil belajar IPS siswa kelas IV SD Gugus Mayor Metra Tahun Ajaran 2015/2016" dengan hasil penelitian menyatakan bahwa model pembelajaran TPS berbasis pendekatan saintifik dapat memberikan waktu lebih banyak kepada siswa untuk memikirkan secara mendalam tentang apa yang telah dijelaskan atau dialami (berpikir, menjawab, dan saling membantu satu sama lain) dengan menggunakan pendekatan saintifik sebagai pendekatannya. Di dalam proses pembelajarannya akan menerapkan sintaks model pembelajaran TPS yang di integrasikan/ dipadukan dengan pendekatan saintifik yang menjadi ciri khas dalam kurikulum 2013. Sehingga terdapat perbedaan yang signifikan hasil belajar IPS antara kelompok siswa yang dibelajarkan melalui model pembelajaran TPS berbasis pendekatan saintifik dengan kelompok siswa yang dibelajarkan melalui pembelajaran konvensional pada siswa kelas IV SD Gugus Mayor Metra Tahun Ajaran 2015/2016.

Hasil penelitian ini didukung oleh hasil penelitian yang dilakukan oleh Sekarini (2014) yang berjudul "Pengaruh model pembelajaran TPS (Think, Pair, Share) berbantuan media audio visual terhadap hasil belajar IPS kelas V SD Gugus I Gusti Ngurah Rai Penatih Tahun Ajaran 2013/2014" dengan hasil penelitian menyatakan bahwa model pembelajaran TPS (Think, Pair, Share) berbantuan media audio visual dapat mengubah pola diskusi kelas dan memungkinkan siswa untuk merespon dan saling membantu satu sama lain, dengan penggunaan media Audio Visual dalam proses pembelajaran dapat lebih menarik minat siswa untuk mengikuti pembelajaran sehingga memudahkan siswa untuk menyerap materi pelajaran. Sehingga terdapat perbedaan yang signifikan hasil belajar IPS antara siswa yang mengikuti model pembelajaran TPS (Think, Pair, Share) berbantuan media audio visual dengan siswa yang mengikuti pembelajaran konvensional. Sehingga dengan menggunakan model pembelajaran kooperatif tipe Think-Pair-Share (TPS) terdapat perbedaan penguasaan 
kompetensi pengetahuan IPS yang signifikan antara kelompok siswa yang mengikuti pembelajaran model kooperatif tipe Think-Pair-Share (TPS) dengan kelompok siswa yang mengikuti pembelajaran konvensional. Adanya perbedaan yang signifikan menunjukkan bahwa penerapan model pembelajaran kooperatif tipe Think-Pair-Share (TPS) berpengaruh positif terhadap penguasaan kompetensi pengetahuan IPS siswa dibandingkan dengan pembelajaran konvensional.

\section{SIMPULAN DAN SARAN}

Berdasarkan hasil penelitian dan pembahasan dapat ditarik kesimpulan sebagai beriku. Pertama, pengaruh yang signifikan model pembelajaran kooperatif tipe think pair share bermuatan kearifan lokal menyama braya terhadap sikap sosial siswa kelas IV Gugus II Kecamatan Abiansemal Kabupaten Badung Tahun Pelajaran 2018/2019. Kedua, pengaruh yang signifikan model pembelajaran kooperatif tipe think pair share bermuatan kearifan lokal menyama braya terhadap penguasaan kompetensi pengetahuan IPS siswa kelas IV Gugus II Kecamatan Abiansemal Tahun Pelajaran 2018/2019. Ketiga, pengaruh yang signifikan model pembelajaran kooperatif think pair share bermuatan kearifan lokal menyama braya secara silmultan terhadap sikap sosial dan penguasaan kompetensi pengetahuan IPS siswa kelas IV Gugus II Kecamatan Abiansemal Tahun Pelajaran $2018 / 2019$.

Saran yang dapat disampaikan, Berdasarkan hasil hasil penelitian yang diperoleh, guru di saran kan lebih kreatif untuk memberikan fasilitas berupa sumber belajar dan kesempatan yang lebih besar bagi siswa pada pembelajaran dengan menggunakan model pembelajaran kooperatif tipe think pair share bermuatan kearifan lokal menyama braya sehingga menciptakan pembelajaran bermakna dan menyenangkan bagi siswa.

Kepada sekolah disarankan agar dapat menciptakan kondisi yang mampu medorong para guru untuk mencoba menerapkan model pembelajaran kooperatif tipe think pair share bermuatan kearifan lokal menyama braya dalam pembelajaran IPS khususnya dan mata pelajaran lain pada umumnya dalam upaya meningkatkan sikap sosial dan penguasaan kompotensi pengetahuan IPS. Peneliti lain di sarankan agar hasil penelitian ini digunakan sebagai refrensi untuk melaksanakan penelitian atau menemukan inovasi kegiatan pembelajaran yang bermakna dan menyenangkan bagi siswa.

\section{DAFTAR RUJUKAN}

Agung, A.A Gede. 2016. Statistik Dasar Untuk Pendidikan. Yogyakarta: Universitas Pendidikan Ganesha.

Huda, Miftahul. 2015. Model-Model Pengajaran dan Pembelajaran Isu-Isu Metodis dan Paradigmatis. Yogjakarta: Pustaka Belajar.

Kunandar. 2015. Penilaian Autentik. Raja Grafindo Persada: Jakarta.

Nurdin, Syafruddin, dkk. 2016. Kurikulum dan Pembelajaran. Jakarta: Raja Grafindo Persada.

Setyosari, Punaji. 2012. Metode Penelitian Pendidikan \& Pengembangan. Jakarta: PT Kharisma Putra Utama.

Sekarini, Ni Made Dewi. 2014. "Pengaruh Model Pembelajaran TPS (Think, Pair, Share) Berbantuan Media Audio Visual Terhadap Hasil Belajar IPS Kelas V SD Gugus I Gusti Ngurah Rai Penatih". Jurnal Pendidikan dan Pengajaran. Volume 2 Nomor 1, (hlm 110). 
Slavin, Robert E. 2010. Cooperative Learning Teori, Riset dan Praktik. Bandung: Nusa Media.

Suardika, I Nengah. 2016. "Pengaruh Model Pembelajaran TPS Berbasis Pendekatan Saintifik Terhadap Hasil Belajar IPS Siswa Kelas IV". Skripsi (tidak diterbitkan). Jurusan Pendidikan Guru Sekolah Dasar. Universitas Pendidikan Ganesha.

Suja, I Wayan. 2010. Kearifan Lokal Sains Asli Bali. Singaraja: Universitas Pendidikan Ganesha.

Widarta, Atmadja, Wahyuni, 2017. "Memaknai Kearifan Lokal Menyama Braya Sebagai Landasan Sistem Pengendalian Manajemen Pada Starlight Restaurant \& Bungalows". Jurusan Akuntansi Program S1. Universitas Pendidikan Ganesha. 